\title{
Immune-inflammatory functions of fibroblasts
}

\author{
M. Jordana*, B. Särnstrand**, P.J. Sime*, I. Ramis*
}

\begin{abstract}
Immune-inflammatory functions of fibroblasts. M. Jordana, B. Särnstrand, P.J. Sime, I. Ramis. CERS Journals Ltd 1994.

ABSTRACT: Inflammation is a response that has evolved over millions of years to become an extremely complex process. This complexity reflects the host's need to deal effectively with a wide variety of potentially injurious agents, as well as the need to incorporate an adequate set of checks and balances. An inappropriately checked response, which occurs rarely, results in disease, either acute or chronic. However, in most instances, inflammation is a beneficial response, essential for survival.

Inflammation comprises an extensive network of cellular interactions implemented by an overwhelming number of molecules. One category of signal includes soluble products, such as neuropeptides, lipid mediators, cytokines and growth factors, most of which can be produced by inflammatory/haemopoietic cells. However, resident structural cells can also produce many of these products and, on this basis only, fibroblasts, epithelial, endothelial and smooth muscle cells should be considered as active contributors to the regulation of the inflammatory response.

Extracellular matrix (ECM) proteins comprise another category of signals. Whilst the most recognized activities of these proteins are those concerned with providing structural tissue integrity, it is clear that they also have powerful inductive effects. Indeed, ECM proteins can influence the shape, movement and state of activation of inflammatory cells in the tissue. Recent evidence indicates that these signals may also play substantial roles in homing of inflammatory cells to certain sites and in the handling of a number of cytokines and growth factors. In so far as fibroblasts are the main producers of ECM proteins, these new data establish an indirect but important role for fibroblasts in the regulation of the inflammatory response. Eur Respir J., 1994, 7, 2212-2222.
\end{abstract}

*Dept of Pathology, McMaster University, Hamilton, Ontario, Canada. **Dept of Pharmacology 1, Preclinical R\&D Astra Draco Pharmaceuticals, Lund, Sweden.

Correspondence: M. Jordana

Dept of Pathology

Health Sciences Centre

Room $4 \mathrm{H} 17$

McMaster University Medical Centre

1200 Main Street West

Hamilton

Ontario

Canada L8N $3 Z 5$

Keywords: Cytokines

extracellular matrix

fibroblasts

growth factors

inflammation

prostaglandin $\mathrm{E}_{2}$

Received: September 131994

Accepted for publication September 16 1994

There are two types of introductions, short and long. Often, short introductions merely introduce, without actually saying much of substance. The reader then feels compelled to read the whole thing. In contrast, long introductions are often like a room with a panoramic view of the contents of the following 11 pages. Introductions that are short and have substance are very rare, requiring almost a touch of genius. Personally, I like long ones, because they provide the reader with freedom to decide what to do about the rest.

\section{Introduction}

\section{About processes}

The "raison d'être" of the lung is to provide gas transfer. From a mechanical standpoint, this requires fairly simple machinery, i.e. a structure that can withstand repeated cycles of inspiration and expiration. This is provided by the extracellular tissue matrix (ECM) that delivers the required mechanical strength and elastic recoil, and, at the same time, gives shape and stability to the tissue. But the lung must also be built to last. In this context, an essential feature of the lung is its geographical location, for although the lung is an internal organ it has a direct and extensive link with the outside world. Such geography implies exposure and, hence, potential for injury, to which the organ responds by mounting an inflammatory reaction, a response no doubt essential for survival. Whilst inflammation has been defined and described in many ways, we elect to characterize it as a preprogrammed reaction designed to fight the intruder at a minimal cost to the host. The former demands an ample repertoire of options to effectively deal with a variety of agents, such as antigens, bacteria, particles, chemicals, etc. Intrinsic to the notion of fighting, is the notion of (tissue) damage and, consequently, the need for repair in order to maintain function. Thus, the structure of the lung must also be prepared to withstand repeated cycles of damage and repair.

\section{About signals}

It is, therefore, apparent that the ability to develop an inflammatory reaction and the necessity to repair are, in fact, a continuum of host responses, which, from a 


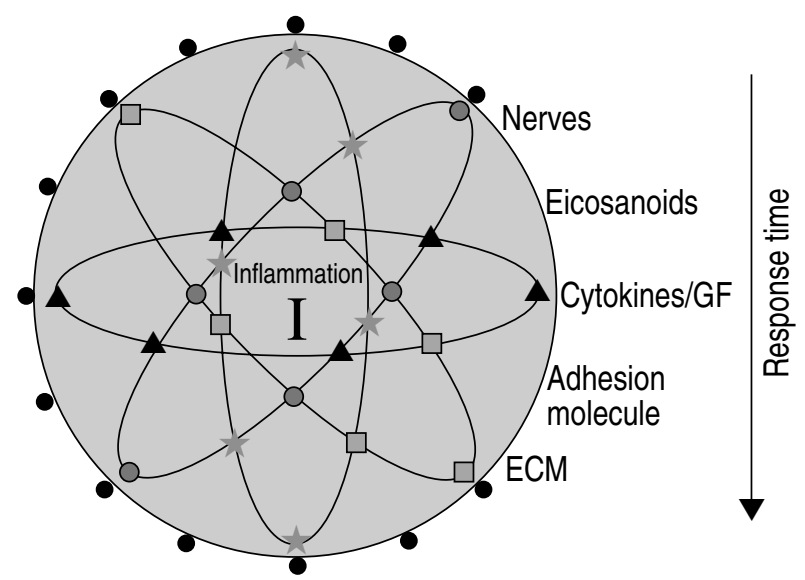

Fig. 1. - Schematic of the various systems of signalling systems involved in the regulation of the inflammatory response. GF: growth factor; ECM: extracellular matrix.

regulatory standpoint, are closely intertwined. Such regulation, often described as enormously complex in order to indicate that we really do not yet understand the operating mechanism, involves multiple intercellular interactions and an embarrassing number of signals (fig. 1). Immediate responses mediated by nerves and nervederived products (neuropeptides) are fired immediately. Very early responses that occur within minutes are mediated by messengers such as the lipid mediators, prostaglandins and leukotrienes, platelet-activating factor (PAF), and nitric oxide. Early responses that develop within hours are mediated by peptide messengers, referred to as cytokines, most, but not all of which, fulfil a proinflammatory role, including the selective upregulation of adhesion molecules in endothelium and epithelium. Finally, the late responses that evolve within hours and days are mediated by two different types of signals; a group of soluble signals comprised of proteins referred to as growth factors, and a group of insoluble signals comprised of the extracellular matrix (ECM) proteins, i.e. connective tissue elements. Whilst there is certainly a temporal element of sequence in these responses, there is, in reality, a great deal of back-and-forth interaction among all of these signals.

\section{About the fibroblast}

Suppose that an inflamed tissue is like the bizarre stage of a complex opera, craftily organized madness! In the ensuing paragraphs, we will develop the argument that whilst the fibroblast may not be the lead singer (a concession to Immunologists Affiliated Inc.), it does play centre stage. Firstly, one of the arguments for the contribution of fibroblasts stems, quite simply, from their ubiquitous presence. Whilst there are few detailed quantitative studies regarding the content of the structural cell compartment in respiratory tissues, it has been reported that fibroblasts account for $35-40 \%$ of cells in the lung interstitium, and this number increases in the lungs of patients with pulmonary fibrosis $[1,2]$. In a recent study, in which we enzymatically dispersed nasal polyp tissues which are tissues undergoing chronic inflammation and fibrosis, we determined that fibroblasts represented close to $50 \%$ of all dispersed cells (S. Finotto, manuscript submitted). Hence, inflammatory cells either residing at, or influxing into, the tissue are literally surrounded by a sea of fibroblasts. Furthermore, it is clear that fibroblasts are the main source of most of the ECM proteins that make up the tissue. Thus, bloodborne cells that enter the tissue move about, on and within, a meshwork of fibroblast-derived products.

A great deal of evidence is now available demonstrating that ECM proteins not only provide and maintain tissue integrity but that they have a powerful inductive capacity, i.e. that they can actively influence shape, movement, activity, growth and differentiation of neighbouring cells. Moreover, it has become apparent in recent years that fibroblasts themselves are also capable of producing many soluble signals, the source of which was initially thought to be restricted to inflammatory cells. Following on our analogy, fibroblasts are not only in, and making the stage, they can sing too!.

\section{Preview}

A full examination of the signals involved in inflammation is well beyond the scope of this essay, and the reader is referred to several reviews on the subject [3-5]. Here, rather than focus on those signals that can affect fibroblast behaviour, we will highlight those that can be produced by fibroblasts themselves. In the section below, "Fibroblast bullets", we will discuss soluble signals, such as lipid mediators, cytokines and growth factors, whilst in the following section, "Fibroblast bricks", we will deal with insoluble signals, i.e. extracellular matrix proteins, especially from the point of view of their potential regulatory role in inflammation. The approach will, by no means, be comprehensive. Instead, we will present selected examples and novel data that, we think, clearly establish the immune-inflammatory capacity of fibroblasts. It is now, we suggest, time for the reader to decide whether or not to continue.

\section{Fibroblast bullets}

\section{Lipid mediators}

Prostaglandin $E_{2}\left(P G E_{2}\right)$. Prostaglandins are oxygenated polyunsaturated fatty acids containing a cyclopentane ring structure. They are produced by the action of the enzyme cyclo-oxygenase on arachidonic acid released from membrane phospholipids. The prostaglandins studied in most detail are those of the E series, particularly $\mathrm{PGE}_{2}$. A variety of agents induce $\mathrm{PGE}_{2}$ production in macrophages and dendritic cells $[6,7]$. In addition, fibroblasts are considered major producers of $\mathrm{PGE}_{2}$, especially upon stimulation by interleukin-1 (IL-1) and tumor necrosis factor- $\alpha$ (TNF- $\alpha)[8,9]$. PGE 2 is generally considered an inhibitory molecule. In fibroblasts, $\mathrm{PGE}_{2}$ inhibits 
proliferation; thus, potentially providing a feedback mechanism for IL-1 or TNF- $\alpha$ induced proliferation [10, 11]. In monocytes, $\mathrm{PGE}_{2}$ inhibits IL-1 production, apparently, by a post-transcriptional mechanism [12].

The data on the effect of prostaglandins on monocyte TNF- $\alpha$ synthesis are more controversial, but it seems that, at least at high concentrations, $\mathrm{PGE}_{2}$ inhibits TNF$\alpha$ synthesis at a transcriptional level [13, 14]. With respect to lymphocytes, $\mathrm{PGE}_{2}$ is also perceived as a suppressive molecule, primarily based on its ability to inhibit T-cell proliferation [15], as well as interleukin-2 (IL-2) and interferon- $\gamma$ (IFN- $\gamma$ ) production by these cells [16]. However, this is a rather simplistic view. Indeed, there is evidence to indicate that $\mathrm{PGE}_{2}$ synergizes with interleukin-4 (IL-4) to induce a remarkable synthesis of immunoglobulin $\mathrm{E}$ and $\mathrm{G}$, (IgE and $\left.\mathrm{IgG}_{1}\right)$ production, whilst at the same time diminishing immunoglobulin $\mathrm{M}$ and $\mathrm{G}_{3}$ (IgM and $\mathrm{IgG}_{3}$ ) production [17, 18].

Furthermore, the inhibitory effect of $\mathrm{PGE}_{2}$ on IL-2 and IFN- $\gamma$ production cannot be viewed as a general T-cell supressor effect, but rather as a selective one, i.e. of the TH1 subset, especially considering that $\mathrm{PGE}_{2}$ has no inhibitory effects on the synthesis of IL-4 or interleukin5 (IL-5), which are cytokines produced by cells of the TH2 subset [19]. Hence, as suggested by PHIPPs et al. [20], $\mathrm{PGE}_{2}$ must be considered a regulatory, rather than a suppressive, modulator of immunity, with a net effect of favouring the development of the TH2 phenotype. A potential implication of this concept relates to asthma. It has recently been shown that inhaled $\mathrm{PGE}_{2}$ protects against exercise-induced bronchoconstriction in asthmatic subjects, suggesting a possible role for this substance in the treatment of the disease [21]. However, evidence discussed in this paragraph cautions about the consequences of the long-term use of $\mathrm{PGE}_{2}$, as it may result in an unwanted switch in the effector phenotype of lymphocytes in the tissue.

\section{Cytokines}

Granulocyte-macrophage colony-stimulating factor (GM$C S F$ ). GM-CSF is a heavily glycosylated protein with molecular weights of 15-30 kD. The basic nonglycosylated peptide backbone of $15 \mathrm{kD}$ is fully active [22-24]. GM-CSF acts in a species-specific manner and interacts with a cell membrane receptor of $45 \mathrm{kD}$ [25], which then transmits a signal through formation of a heterodimeric structure with a surface molecule which is a common signal-transducing pathway for the activity of interleukin3 (IL-3) and IL-5 [26].

This cytokine, like the other colony-stimulating factors, granulocyte-CSF (G-CSF) and macrophage-CSF (M-CSF), was initially identified by its effects on myeloid stem cells, i.e. inducing differentiation to mature inflammatory cells, granulocytes and macrophage/monocytes in the case of GM-CSF. However, several additional biological activities of GM-CSF on mature inflammatory cells apply more directly to chronic inflammation. For example, this cytokine has been shown to promote survival, by preventing apoptosis, and to induce activation of monocytes, eosinophils and neutrophils in vitro [2730].

The role of GM-CSF in the development of fibrosis has received less attention, and the information available is controversial. On the one hand, RUBBIA-BRANDT et al. [31] used mini-osmotic pumps to deliver low levels of cytokines into a subcutaneous site in rats, and showed that GM-CSF induced an accumulation of myofibroblasts, i.e. of fibroblasts-like cells containing $\alpha$-smooth muscle actin. Effectively, these cells are fibroblasts with contractile characteristics, the presence of which has been documented in pulmonary fibrosis [32], asthma [33], and nasal polyposis (M. Nonaka, manuscript in preparation). On the other hand, in a model of bleomycin-induced pulmonary fibrosis, PIGUET and co-workers [34] showed that GM-CSF reduced the severity of the parenchymal lesions, whilst treatment with anti-GM-CSF antibodies aggravated the extent of fibrosis. The ability of GMCSF to induce IL-1 receptor antagonist (IL-1ra) and soluble TNF- $\alpha$ receptor in alveolar macrophages and neutrophils has been invoked as a possible basis for the anti-fibrogenic effect of GM-CSF [35-37].

The chemokine family. This is a group of low molecular weight proteins, which are potent chemoattractants for leucocytes. The family is comprised of two subfamilies (C-X-C and C-C) depending on whether there is an amino acid present between the first two cysteines in the conserved motif. Interleukin 8 (IL-8) and macrophage inflammatory peptide 2 (MIP-2) are members of the C$\mathrm{X}-\mathrm{C}$ subfamily, which primarily recruits neutrophils, whilst monocyte chemoattractant protein-1 (MCP-1) and macrophage inflammatory peptide- $1 \alpha(\mathrm{MIP}-1 \alpha)$ are members of the $\mathrm{C}-\mathrm{C}$ family, which rather selectively recruit monocytes and lymphocytes [38].

IL-8 is an $8.4 \mathrm{kD}$ protein, that is relatively resistant to proteolysis and denaturation. In addition to being a potent and relatively selective chemoattractant for neutrophils [39], IL-8 activates neutrophils, increasing expression of the integrin CD11b/CD18, initiating a respiratory burst, promoting exocytosis of damaging lysosomal enzymes, and increasing production of lipid mediators, such as leukotriene $\mathrm{B}_{4}\left(\mathrm{LTB}_{4}\right)$ [40]. Neutrophils are not the exclusive target of IL- 8 , as it has been shown that this cytokine stimulates histamine and leukotriene release by IL-3 primed basophils [41], and it probably has inductive effects on eosinophils. The documentation of increased levels of IL-8 compartmentalized within the alveolar space in idiopathic pulmonary fibrosis (IPF) suggests that the main source of this cytokine, at least in this disease, is the alveolar macrophage [38].

MCP-1, in addition to being chemotactic, stimulates the respiratory burst and the release of lysosomal enzymes in monocytes, and induces tumoricidal activity [42, 43]. In patients with IPF, MCP-1 has been found to be increased in the alveolar space and, in contrast to IL-8, in the pulmonary interstitium as well [38]. MCP-1 and MIP$1 \alpha$ have recently been shown to be involved in granuloma formation [43] and, in this regard, LUKACS and co-workers [44] have shown that in vivo neutralization of MIP-1 $\alpha$ can alter the size and development of granulomas. 
The fibroblast edge. It is evident that colony-stimulating factors and members of the chemokine family are capable of mediating a wide range of proinflammatory effects. In addition, all of them have been initially identified as products produced by the classical immune-inflammatory cells (lymphocytes and monocytes) upon appropriate conditions of stimulation $[45,46]$. However, it is now clear that this group of cytokines can also be produced by other cell types, particularly structural cells, including fibroblasts, epithelial, endothelial and smooth muscle cells [47-52]. It is of interest to note that optimal conditions for the synthesis of these cytokines require IL-1 and/or TNF- $\alpha$ stimulation. Furthermore, there is evidence that fibroblasts may express an upregulated effector phenotype, at least for some of these cytokines, during chronic inflammation. For example, LuKACs and co-workers [43] have shown that fibroblasts isolated from schistosomal-induced hepatic granulomas produce exvivo increased amounts of MCP-1 and MIP- $\alpha$ [43]. Similarly, we have shown that fibroblasts isolated from nasal polyp tissues, i.e. tissues undergoing severe and longstanding inflammation, produce greater amounts of GM-CSF compared to fibroblasts isolated from the normal nasal mucosa [53]. In addition, it appears that pulmonary fibroblasts from IPF patients produce greater amounts of MIP- $1 \alpha$ after challenge with IL-1 than fibroblasts from healthy subjects [38]. Hence, it may be that in defined pathological processes, fibroblast-derived MCP-1, MIP$1 \alpha$ or GM-CSF play an important regulatory role.

\section{Growth factors}

Platelet-derived growth factor $(P D G F)$. PDGF is a highly cationic glycoprotein of 28-35 kD weight, composed of two polypeptide chains (A and B) linked as a dimer by disulphide bonds. The PDGF-B chain is related to the product of the $c$-sis oncogene, and the molecules interact with two types of receptors having homo- and heterodimeric structures. Three forms of PDGF have been described; AA and BB homodimers, and the AB heterodimer [54], all of which have similar biological effects. The main role played by PDGF is as a proliferation and chemotactic factor, particularly for fibroblasts and smooth muscle cells. This mitogen, first discovered as a granuleassociated glycoprotein in platelets, can also be produced by alveolar macrophages in vitro, as well as by fibroblasts, endothelial, epithelial and smooth muscle cells [55]. There is evidence that fibroblast proliferation stimulated by IL1, TNF- $\alpha$ and transforming growth factor (TGF- $\beta$ ) is in fact mediated via induction of PDGF and PDGF receptors on the fibroblast and, in addition, exogenously added PDGF can also induce PDGF production by fibroblasts [56-58]. This establishes a potential autocrine loop of PDGF upregulation in fibroblasts, and suggests a direct connection between the inflammatory and reparative responses.

Alveolar macrophages isolated from the bronchoalveolar lavage (BAL) of patients with IPF have been shown to produce PDGF [59]. Expression of PDGF messenger ribonucleic acid (mRNA) and protein localization have also been observed directly in the lung tissue [60]. However, these in vivo studies showed that epithelial cells were the primary source of PDGF immunoreactivity in the tissue. Thus, whether fibroblasts in IPF have, with respect to PDGF, an effector contribution or are merely a target cell remains to be elucidated. FABISIAK et al. [61] examined expression of PDGF-B mRNA in the rat lung during chronic hyperoxia, and showed that increased expression of this gene was temporally self-limited. Furthermore, the role of PDGF in patients with adult respiratory distress syndrome (ARDS) is inconclusive [62]. Thus, whilst PDGF probably plays a reparative role after injury, its involvement in the development of fibrosis is much less certain. However, it is possible that persistent expression of PDGF perpetuated by chronic injury, chronic stimulation, or an irreversible change in the cells phenotype could be involved in such an event.

Transforming growth factor- $\beta$ (TGF- $\beta$ ). TGF- $\beta$ refers to a family of cytokines initially named for their ability to induce transformation of cells to anchorage independent growth, but now recognized to be very pleiomorphic molecules. There are five subtypes identified to date, but only three are known to be present in mammalian tissue, and, of these, TGF- $\beta 1$ is the most prominent. This molecule is a protein of $25 \mathrm{kD}$, made up of two identical chains linked by disulphide bonds [63, 64]. TGF- $\beta$ is normally secreted as an inactive high molecular weight precursor, that requires either acid treatment or enzymatic cleavage for activation, although in some instances, such as with monocytes and neutrophils, it may be released in active form [65]. TGF- $\beta$ is chemotactic for fibroblasts, and can cause fibroblasts from both normal and remodelling lung to proliferate [64]. Interestingly, this mitogenic effect appears to be mediated through induction of PDGF and PDGF receptors on the responding cell [66]. Whilst the alveolar macrophage has been considered the main source of TGF- $\beta$ for many years, it is now clear that lung fibroblasts can also synthesize TGF- $\beta$ [64]. An important regulatory mechanism for lung fibroblast production of TGF- $\beta$ is auto-induction, a process whereby TGF- $\beta$ gene expression is increased after exposure to exogenous TGF- $\beta$ [67]. This could, potentially, result in chronic activation and possible differentiation to a more "aggressive" phenotype.

Production of many extracellular matrix components, such as collagens [68], fibronectin [69] and its receptor, chondroitin and dermatan sulphate proteoglycans [70], hyaluronan [71] and integrins, are stimulated by TGF- $\beta$. Conversely, TGF- $\beta$ decreases the synthesis of matrix degrading enzymes, such as collagenases, and increases the synthesis of protease inhibitors [64]. Of course, the net outcome of this series of effects would be increased deposition of extracellular matrix components. In human pulmonary disorders, LIMPER et al. [72] examined lung biopsies from patients with IPF, and found TGF- $\beta$ mRNA localized to areas of macrophage aggregation using in situ hybridization techniques, and TGF- $\beta$ protein by immunohistochemistry in alveolar buds populated by fibroblasts. In other studies, KHALIL et al. [73] demonstrated TGF- $\beta$ localization in bronchiolar epithelium of 
patients with advanced IPF, but not in normal subjects, and Broekelman et al. [74] found TGF- $\beta$ mRNA and protein at sites of extracellular matrix deposition in patients with IPF, but not in biopsies of patients who had ongoing inflammation but little or no associated fibrosis.

In addition to its role in the regulation of matrix proteins expression, TGF- $\beta$ has a puzzling array of effects on inflammatory cells. For example, TGF- $\beta$ has been shown to be a chemoattractant for monocytes, neutrophils and lymphocytes at very low doses, and to increase the synthesis of a variety of proinflammatory cytokines, such as IL-1, TNF- $\alpha$, IL- 6 and MIP- $1 \alpha$ in resting monocytes at picomolar concentrations. However, TGF- $\beta$ is also a well-known immunosupressor and anti-inflammatory cytokine, that can induce a broad spectrum of effects, including inhibition of B-cell proliferation and immunoglobulin secretion, inhibition of T-cell proliferation and cytotoxicity, suppression of natural and lymphokineactivated killing by large granular lymphocytes, inhibition of T-lymphocyte adhesion to endothelium, downregulation of macrophages, and antagonism of most of the effects of TNF- $\alpha[63,75-77]$. The importance of the anti-inflammatory role of TGF- $\beta$ is emphasized in a recent study by Schull et al. [78], using a "knock out" approach to develop TGF- $\beta$ deficient mice. All of these animals died of a wasting syndrome and widespread inflammation about 20 days after birth. Examination of cytokine gene expression showed an upregulation of TNF$\alpha$, MIP- $1 \alpha$ and IFN- $\gamma$ in a variety of tissues including the lung. Together, these data suggest that, as indicated by OpPenHEIM and NeTA [79], "the actions of TGF- $\beta$ reflect a pattern whereby TGF- $\beta$ switches on resting cells and switches off activated cells".

\section{Other growth factors}

The insulin-like growth factors (IGFs), IGF-I and IGFII are small peptides acting as progression factors [80]. IGF-I (somatomedin C) is a basic peptide of $7.6 \mathrm{kD}$, and IGF-II is a neutral peptide of $7.5 \mathrm{kD}$. Little or no free IGF is present in serum or tissues, because it is bound to a number of binding proteins, which can either enhance or inhibit the cellular actions of IGFs. Two welldocumented characteristics of the IGFs are their capacity to induce cellular proliferation and differentiation, these actions often being exerted in concert with other cytokines. IGFs play a role during foetal development and in postnatal somatic growth. IGFs, their receptors and binding proteins are expressed in foetal as well as in postnatal lung; foetal lung fibroblasts synthesizing both IGF-I and IGF-II [81]. However, their role in lung repair following injury has received little attention. Tracheal epithelial cells do not synthesize IGF-I but they have type I receptors. Therefore, they could respond to IGF-I localized to submucosal fibroblasts. This paracrine action by IGF-I could play an important role during airways epithelial cell repair [82]. Also, IGF-I could play a role in pulmonary disorders characterized by fibroblast proliferation, since its autocrine production is partly responsible for fibroblast proliferation after exposure to PDGF of fibroblast growth factor (FGF) [83].

\section{Fibroblast bricks}

\section{The plot}

The notion that in a tissue undergoing inflammation there is a blast after blast of bullets (lipid mediators, cytokines and growth factors) wandering around the tissue randomly hitting targets (responding cells) is, out of respect for nature, probably a gross and rather pathetic simplification. Neither is it cost-effective. Indeed, even in an inflamed tissue, distances between cells are considerable, and it is quite conceivable that soluble signals can only act at very short distances, not so much because of short half-lives but because of degradation upon exposure to proteolytic enzymes. In addition, injury or damage in an inflamed tissue is, at a microscopic level, often not of a homogeneous, but rather of a patchy nature. It would then appear that to accumulate and activate inflammatory cells at certain tissue sites would be strategically advantageous to the host. There is now sufficient evidence to suggest that the extracellular matrix probably plays a major role in preventing the random movement of cells and soluble mediators within the tissue. We view this matrix as the physical continuum between cells, from a structural standpoint, and as a transmitter of tissue messages, from a functional standpoint.

\section{The cast}

The interstitial fibroblast is the major cell type responsible for the synthesis of extracellular matrix (ECM) proteins. Collagens comprise over one third of the dry mass of the lung [84-86]. Fourteen different types of collagen have so far been described, with collagens types I and III been the most abundant in the lung interstiium (ratio 3-6:1), followed by types V and VI. Type IV is the main collagen in the basement membrane. Approximately another third of the dry mass of the lung is made up of elastin [87], with the remaining being comprised of various amounts of fibronectin, proteoglycans (PGs), hyaluronan (HA), laminin, and minor matrix macromolecules, such as vitronectin and thrombospondin [88]. Collagens form various types of fibrils, which together with elastin give the tissue tensile strength and elasticity.

In the interfibrillar space, fibronectin, HA and PGs form a meshwork that keeps the collagen and elastin fibres apart, contribute to fibril formation and orientation, and, by virtue of their large hydration capacity and anionic properties, can exert swelling pressure. The connective tissue matrix changes dramatically during inflammation. Within hours, a cascade of degrading enzymes breaks down ECM proteins. Whilst this loss of integrity might be viewed as a paradigm of tissue damage, it also provides the tissue with some notable advantages, as loosening of the connective matrix makes it easier for 
the inflammatory cells to migrate to the sites of injury. The role of extracellular matrix proteins in maintenance of tissue integrity and healing processes will not be discussed in this report. Instead, we will provide several examples that illustrate the ability of extracellular matrix proteins, by extrapolation of fibroblasts, to regulate the inflammatory response.

\section{The play}

Act I - "Going places". In order to accomplish their function, immune-inflammatory cells must be directed to the appropriate tissue sites. The mechanisms regulating the migration and homing of these cells are just beginning to be unveiled, including novel data indicating that proteoglycans are involved in this process.

Proteoglycans are proteins that carry an unusual carbohydrate, a glycosaminoglycan (GAG). The GAG chain consists of a number of repeating disaccharide units in a linear arrangement. The carbohydrate backbones consist of hexosamine, and either hexuroic acid or galactose arranged in an alternating sequence containing sulphate substituents in various positions that make the GAG chains negatively charged. The alternations in the disaccharide unit give different types of GAG chains, such as heparan sulphate (HS), heparin or chondroitin (CS) and dermatan sulphate (DS), and keratan sulphate. The many different types of core proteins and the diversity in GAG chains result in a family of proteoglycans that is, appropriately, very large, considering the many different functions and locations of PGs (see [89-91] for excellent reviews on proteoglycans).

There are PGs that are intracellular, such as serglycine, thought to be involved in the storage of granular components of various types in haemopoietic cells. There is also a large family of extracellular PGs that are found mainly associated with pericellular matrices and with the cell surface, which mediate a broad spectrum of biological functions. The negative charge of PGs, especially the sulphated ones, makes it possible for GAG to attach to many substances. However, charge is not the only basis of binding, as a number of proteins can bind specifically to certain types of GAG chains. An example of such is CD44, which represents a family of integral membrane glycoproteins expressed on the surface of numerous cell types, including haemopoietic cells, epithelial cells and fibroblasts, although there may be some differences in the core protein and/or the GAG chains in CD44 expressed in structural cells and in haemopoietic cells $[92,93]$. In particular, there has been considerable interest in the role of CD44 in lymphocyte homing. Recently, it has been shown that the ligand for CD44 is the glycosaminoglycan hyaluronan (HA) [94], although CD44 can also bind to collagen and fibronectin. Interestingly, many normal cells express CD44 but do not bind $\mathrm{HA}$, suggesting that ligand activation may require a specific activating event [95]. In this regard, MURAKAMI et al. [96] have shown that CD44-mediated HA-binding can be induced in B-cells cultured for several days in IL-5, and LESLEY et al. [97] have recently demonstrated similar binding in T-cells after immunological activation in vivo using an allogenic response model. These authors also showed that most of the cytotoxic effector cells were found in the HA-binding population. Whilst the precise mechanisms remain unknown, the evidence suggests that the CD44-HA interaction may play an important role in directing activated lymphocytes to sites of inflammation, and it is likely that similar homing mechanisms will be unveiled for other inflammatory cells.

Act II - "Thriving on Solid Ground". An effective tissue inflammatory response needs to be co-ordinated, i.e. needs to involve complex sets of cell-cell and cell-matrix interactions. Integrins are a family of cell surface proteins involved in cell adhesion in general but, primarily, in cell-matrix interactions. Integrins consist of two subunits, $\alpha$ and $\beta$. A number of $\alpha$ and $\beta$ subunits are now known, and combinations of these subunits form at least 16 distinct integrins [98]. As pointed out by RuOSLAHTI [99], this diversity of integrins provides cells with varied capabilities to recognize adhesive substrates. A number of extracellular matrix proteins, such as fibronectin, laminin, collagens, thrombospondin and vitronectin are the ligands for integrins. A major discovery in the field of integrin-matrix interactions has been the recognition that many integrins bind to the extracellular matrix via the Arg-Gly-Asp (RGD) sequence [100], which was first identified in fibronectin, but it is now clear that it is also present in other matrix proteins. For example, the $\beta_{1}$ family of integrins binds laminin and collagen receptors, in addition to fibronectin.

The ability of blood-borne cells entering the tissue to interact, via integrins, with matrix components implies more than a passive attachment. Mechanically, such interaction may provide cells with traction to move about. Functionally, it is evident that matrix components are involved in growth, differentiation and activation of haemopoietic cells [101-103]. For example, there is evidence that adherence of monocytes to collagen substrates enhances phagocytosis and killing of opsonized bacteria, an effect probably mediated through the upregulation of both complement and Fc receptors [104]. Adherence of monocytes to collagen, but not to fibronectin, has been shown to induce high levels of TNF- $\alpha$ expression as well [105], and we have shown that culture of alveolar macrophages on a fibroblast-derived extracellular matrix results in a sustained expression of IL-1 and IL-6 after lipopolysaccharide (LPS) stimulation [106]. Recently, ANwar et al. [107] have shown that fibronectin prolongs eosinophil survival, and that this effect appears to be mediated in an autocrine fashion through the stimulation of GM-CSF synthesis.

Therefore, the accumulation and activation of specific inflammatory cell types at distinct sites probably involves a complex interplay of integrin expression on blood cells on the one hand, and the relative proportions and distribution of different extracellular matrix proteins on the other. This is not merely of academic interest, as identification of factors important in cell-matrix binding, such as the RGD sequence already mentioned, can be exploited to design compounds to inhibit such interactions. 


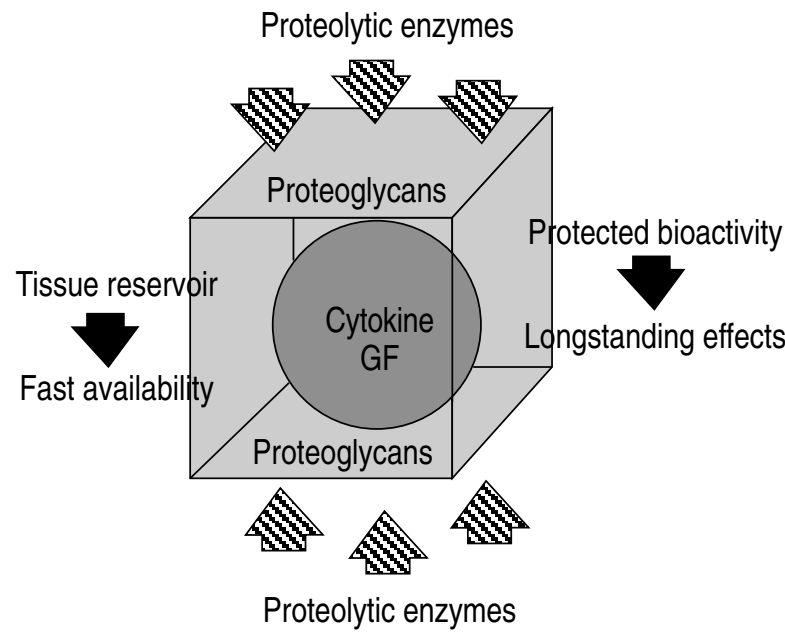

Fig. 2. - The cube in the diagram represents the tissue. Cytokines or growth factors (GF) bound to matrix structures, such as certain proteoglycans, may be protected from degradation. Such protection may have positive or negative consequences.

Act III - Hidden Treasures. The ability of proteoglycans to bind proteins has, potentially, many implications. At the beginning of this section, we alluded to the functional limitations of cytokines and growth factors. In this context, evidence demonstrating the ability of PGs to bind to these soluble molecules is relevant. For example, basic fibroblast growth factor (bFGF) binds to heparin or heparan sulphate chains of PGs [108]. The cell surface proteoglycan, with which it probably interacts, is syndecan. GM-CSF and IL-3 have also been shown to bind the heparan sulphate moiety of proteoglycans [109].

It has been suggested that binding of these molecules to matrix proteoglycans may provide a "tissue reservoir" for these products, which could become immediately available during inflammation (fig. 2). For example, heparin (coming, perhaps, from mast cells) could displace the growth factor/cytokine from heparan sulphate [110]. Alternatively, proteolytic cleavage of the proteoglycans could mobilize PG fragments with the growth factor still bound [111]. What makes this latter event attractive is that there is evidence, at least for bFGF, that this growth factor is protected from proteolytic degradation when complexed with PGs, implying that its biological activity would survive in this stored form [112]. In a number of situations, such as in bone marrow haemopoiesis, protection of cytokine/growth factor bioactivity from degradation appears as a beneficial outcome, as one requires an ongoing operative process. However, in situations where what is required is a self-limited response, such as inflammation, the long-term presence in the tissue of powerful inductive molecules may, in fact, contribute to the perpetuation of the response (fig. 2).

There is also evidence that TGF- $\beta$ binds to PGs, but with several major differences compared to the interactions discussed in the previous paragraph. Firstly, in contrast to bFGF, IL-3 and GM-CSF, which bind to the GAG chains, TGF- $\beta$ binds to the core protein. As previously mentioned for bFGF there are two sides to the TGF- $\beta$ PGs interaction. On the cell surface side, one of the three receptors identified for TGF- $\beta$ is a proteoglycan called betaglycan [113]. On the matrix side, TGF$\beta$ binds to a proteoglycans called decorin. Decorin, as well as other structurally related proteoglycans, such as biglycan and fibromodulin, probably have significant roles in aspects of structural organization, such as fibril formation of collagens I and II. Secondly, and what makes the TGF- $\beta$ decorin interaction intriguing is that, on one hand, decorin binds TGF- $\beta$ and inhibits its activity, whilst on the other hand, decorin production by a variety of cells is stimulated by TGF- $\beta$ [114].

WESTERGREN-THORSSON et al. [115] have recently described the changes in these PGs together with TGF- $\beta$ in an experimental model of bleomycin-induced pulmonary fibrosis. In agreement with previous data, the increase in TGF- $\beta$ in the lung preceded the increase in collagen. The change in TGF- $\beta$ also preceded the increase in biglycan. But, interestingly, decorin changes moved in the opposite direction, i.e. lung decorin decreased as TGF$\beta$, and biglycan increased, suggesting, as pointed out by the authors, a distinct role for these PGs in the fibrotic process. Since decorin binds and neutralizes TGF- $\beta$ activity, a decreased level of decorin could allow further TGF- $\beta$ effects. Hence, it is tempting to speculate that the balance in the tissue between decorin and TGF- $\beta$ may substantially determine the biological outcome.

An extension of this concept has been tested by BORDER et al. [116] in an experimental model of glomerulonephritis, where the intravenous administration of decorin prevented the increased production of extracellular matrix proteins and attenuated disease features, such as proteinuria. Another extracellular matrix protein capable of binding TGF- $\beta$ is thrombospondin. However, by way of contrast to decorin, this interaction forms a biologically active complex that is protected from protease degradation [117]. Hence, the relative amounts of matrix proteins generated during inflammation may determine, at least in part, the amount of TGF- $\beta$ actually available in an active form.

\section{Summary}

Fibroblasts can synthesize a number of cytokines, particularly upon stimulation with IL-1 and TNF- $\alpha$, which are produced early in the inflammatory reaction, primarily by monocyte/macrophages. It is also evident that, in certain conditions, fibroblasts express an upregulated effector phenotype for some cytokines. These suggest that fibroblast-derived cytokines may play a significant role in the amplification and, perhaps, perpetuation of the inflammatory response. The ability of fibroblasts to produce $\mathrm{PGE}_{2}$, again especially upon IL-1 and TNF- $\alpha$ stimulation, and the documented effects of this mediator on lymphocytes suggests a role for fibroblasts in the regulation of immune responses. The evidence demonstrating that fibroblasts can produce a variety of growth factors to which they can themselves also respond, suggests a central role in the regulation of the reparative response, possibly involving autocrine regulatory loops. Finally, it is abundantly clear that extracellular matrix 
proteins can induce many effects, not only in tissue structural cells but also in haemopoietic cells. In so far as fibroblasts are the main producers of such matrix products, this establishes a further, perhaps critical, regulatory role of these cells in inflammation. Such a broad contribution to the development of immuneinflammatory responses justifies, in our view, the consideration of fibroblasts as immune-inflammatory cells.

We can expect, in the years to come, an exponential increase in knowledge of eicosanoid mediators, cytokines, growth factors, extracellular matrix proteins and integrins. However, the real clues will, we feel, emerge primarily from an understanding of how these various signalling systems interact with one another.

Acknowledgements: The authors are thankful to the Medical Research Council (Canada), the Ontario Thoracic Society and Astra Canada Inc. for supporting their research work cited in this manuscript. M.J. is a Career Scientist of the Ontario Ministry of Health. P.J.S. is supported by a Travelling Fellowship from the MRC (UK). The authors gratefully acknowledge the secretarial assistance of $\mathrm{M}$. Kiriakopoulos.

\section{References}

1. Rennard SI, Bitterman PB, Crystal RG. Pathogenesis of the granulomatous lung diseases. IV. Mechanisms of fibrosis. Am Rev Respir Dis 1984; 130: 492-496.

2. Rennard SI, Ferrans VJ. Lung connective tissue. In: Witschi H, ed. Mechanisms in Respiratory Toxicology. Vol. 2. Boca Raton, Florida, CRC Reviews, 1982; pp. $115-153$.

3. Strieter RM, Lukacs NW, Standiford TJ, Kunkel SL. Cytokines. 2. Cytokines and lung inflammation: mechanisms of neutrophil recruitment to the lung (Review). Thorax 1993; 48(7): 765-769.

4. Gauldie J, Jordana M, Cox G. Cytokines and pulmonary fibrosis (Review). Thorax 1993; 48(9): 931-935.

5. Henderson WR Jr. Eicosanoids and platelet-activating factor in allergic respiratory diseases (Review). Am Rev Respir Dis 1991; 143 (5 Pt 2): S86-90.

6. Bonney RJ, Naruns P, Davies P, Humes JL. Antigenantibody complexes stimulate the synthesis and release of prostaglandins by mouse peritoneal macrophages. Prostaglandins 1979; 18: 605-616.

7. Fidler IJ, Nii A, Ulsugi T, Brown D, Bakouche O, Kleinerman E. Differential release of TNF- $\alpha$, IL-1 and $\mathrm{PGE}_{2}$ by human blood monocytes. Lymphokine Res 1990; 9(4): 449-463.

8. Lin LL, Lin AY, DeWitt DL. Interleukin-1 $\alpha$ induces the accumulation of cytosolic phospholipase $\mathrm{A}_{2}$ and the release of prostaglandin $\mathrm{E}_{2}$ in human fibroblasts. $J$ Biol Chem 1992; 267(33): 23451-23454.

9. Dayer JM, Beutler B, Cerami A. Cachectin/tumor necrosis factor stimulates collagenases and prostaglandin $\mathrm{E}$ production by human synovial cells and dermal fibroblasts. J Exp Med 1985; 162: 2163-2166.

10. Elias J. Tumour necrosis factor interacts with interleukin1 and interferons to inhibit fibroblast proliferation via prostaglandin dependent and independent mechanisms. Am Rev Respir Dis 1988; 138: 652-658.

11. Fine A, Goldstein RH. The effect of $\mathrm{PGE}_{2}$ on the activation of quiescent lung fibroblasts. Prostaglandins 1987; 33(6): 903-913.
12. Knudsen PJ, Dinarello C, Strom TB. Prostaglandins posttranscriptionally inhibit monocyte-expression of interleukin1 activity by increasing cyclic adenosine monophosphate. J Immunol 1986; 137: 3187-3194.

13. Renz H, Gong JH, Schmidt A, et al. Release of tumour necrosis factor- $\alpha$ from macrophages: enhancement and supression are dose-dependently regulated by prostaglandin $\mathrm{E}_{2}$ and cyclic nucleotides. J Immunol 1988; 141: 2388-2393.

14. Kunkel SL, Spengler M, May MA, et al. Prostaglandin $\mathrm{E}_{2}$ regulates macrophage-derived tumor necrosis factor gene expression. J Biol Chem 1988; 263: 5380-5384.

15. Goodwin JS, Bankhurst AD, Messner RP. Suppression of human T-cell mitogenesis by prostaglandin. J Exp Med 1977; 146: 1719-1734.

16. Snijdewint FGM, Kalinski P, Wierenga EA, Bos JD, Kapsenberg ML. Prostaglandin $\mathrm{E}_{2}$ differentially modulates cytokine secretion profiles of human T-helper lymphocytes. J Immunol 1993; 150(12): 5321-5329.

17. Roper RL, Conrad DH, Brown DM, Warner GL, Phipps RP. Prostaglandin $E_{2}$ promotes IL-4 induced IgE and $\mathrm{IgG}_{1}$ synthesis. J Immunol 1990; 145(8): 2644-2651.

18. Phipps RP, Roper RL, Stein SH. Regulation of B-cell tolerance and triggering by macrophages and lymphoid dendritic cells. Immunol Rev 1990; 117: 135-158.

19. Betz M, Fox BS. Prostaglandin $\mathrm{E}_{2}$ inhibits production of TH1 lymphokines but not of TH2 lymphokines. $J$ Immunol 1991; 146: 108-113.

20. Phipps RP, Stein SH, Roper RL. A new view of prostaglandin $\mathrm{E}$ regulation of the immune response. Immunol Today 1991; 12: 349-352.

21. Melillo E, Woolley KL, Manning PJ, Watson RM, O'Byrne $\mathrm{PM}$. Effect of inhaled $\mathrm{PGE}_{2}$ on exercise-induced bronchoconstriction in asthmatic subjects. Am J Respir Crit Care Med 1994; 149: 1138-1141.

22. Wong GG, Witek JS, Temple PA, et al. Human GMCSF: molecular cloning of the complementary DNA and purification of the natural and recombinant proteins. Science 1985; 228: 810-815.

23. Cantrell MA, Anderson D, Cerretti DP, et al. Cloning, sequence and expression of a human granulocyte/macrophage colony-stimulating factor. Proc Natl Acad Sci USA 1985; 82: 6250-6254.

24. Lee F, Yokota T, Otsuka T, et al. Isolation of cDNA for a human granulocyte-macrophage colony-stimulating factor by functional expression in mammalian cells. Proc Natl Acad Sci USA 1985; 82: 4360-4364.

25. Gearing DP, King JA, Gough NM, Nicola NA. Expression cloning of a receptor for human-granulocyte-macrophage colony-stimulating factor. EMBO J 1989; 8: 36673676.

26. Miyajima A, Hara T, Kitamura T. Common subunits of cytokine receptors and the functional redundancy of cytokines. TIBS 1992; 17: 378-382.

27. Gauldie J, Jordana M, Cox G. Myeloid growth factors in the lung. In: Kelley J, ed. Cytokines of the Lung. New York, Marcel Dekker, 1992; pp. 383-402.

28. Vancheri C, Gauldie J, Bienenstock J, et al. Human lung-derived granulocyte-macrophage colony-stimulating factor (GM-CSF) mediates eosinophil survival in vitro. Am J Respir Cell Mol Biol 1989; 1: 289-295.

29. Zhou X, Ohtoshi T, Ralph P, Gauldie J, Jordana M. Human upper airway structural cell-derived cytokines support human peripheral blood monocyte survival: a potential mechanism for monocyte/macrophage accumulation in the tissue. Am J Respir Cell Mol Biol 1992; 6: 212-218. 
30. Lindemann A, Riedel D, Oster W, et al. Granulocytemacrophage colony-stimulating factor induces interleukin1 production by human polymorphonuclear neutrophils. J Immunol 1988; 140: 837-839.

31. Rubbia-Brandt L, Sappino A, Gabbiani G. Locally applied GM-CSF induces the accumulation of $\alpha$-smooth muscle actin containing fibroblasts. Virchows Arch (Cell Pathol) 1991; 60: 73-82.

32. Mitchell J, Woodcock-Mitchell J, Reynolds S, et al. Alpha-smooth muscle actin in parenchymal cells of bleomycin-injured rat lung. Lab Invest 1989; 60: 643650.

33. Brewster CEP, Howarth PH, Djukanovic R, Wilson J, Holgate ST, Roche WR. Myofibroblasts and subepithelial fibrosis in bronchial asthma. Am J Respir Cell Mol Biol 1990; 3: 507-511.

34. Piguet PF, Grau GE, de Kossodo S. Role of granulocytemacrophage colony-stimulating factor in pulmonary fibrosis induced in mice by bleomycin. Exp Lung Res 1993; 19: 579-587.

35. Piguet PF, Vesin C, Grau GE, Thompson RC. Interleukin1 receptor antagonist (IL-1ra) prevents or cures pulmonary fibrosis elicited in mice by bleomycin or silica. Cytokine 1993; 5: 57-61.

36. Roux-Lombard P, Modoux C, Dayer JM. Production of interleukin-1 (IL-1) and a specific IL-1 inhibitor during human monocyte-macrophage differentiation: influence of GM-CSF. Cytokine 1989; 1: 45-51.

37. Porteu F, Nathan C. Shedding of tumor necrosis factor receptors by activated human neutrophils. J Exp Med 1990; 172: 599-607.

38. Strieter RM, Koch AE, Antony VB, Fick RB, Standiford TJ, Kunkel SL. The immunopathology of chemotactic cytokines: the role of interleukin-8 and monocyte chemoattractant protein-1. J Lab Clin Med 1994; 123: 183-197.

39. Matsushima K, Morishita K, Yoshimura T, et al. Molecular cloning of a human monocyte-derived neutrophil chemotactic factor (MDNCF) and the induction of MDNCF mRNA by interleukin-1 and tumor necrosis factor. $J$ Exp Med 1988; 167: 1883-1893.

40. Baggiolini M, Walz A, Kunkel SL. Neutrophil-activating peptide-1/interleukin-8, a novel cytokine that activates neutrophils. J Clin Invest 1989; 84: 1045-1049.

41. Dahinden CA, Kurimoto Y, De Weck A, Lindley I, Dewald B, Baggiolini M. The neutrophil-activating peptide NAF/NAP-1 induces histamine and leukotriene release by interleukin-3 primed basophils. J Exp Med 1989; 170: 1787-1792.

42. Schall TJ. Biology of RANTES/sis cytokine family. Cytokine 1991; 3: 165-183.

43. Lukacs NW, Chensue SW, Smith RE, et al. Production of monocyte chemoattractant- 1 and macrophage inflammatory protein- $1 \alpha$ by inflammatory granuloma fibroblasts. Am J Pathol 1994; 144: 711-718.

44. Lukacs NW, Kunkel SL, Strieter RM, Warmington K, Chensue SW. The role of macrophage inflammatory protein-1 alpha in Schistosoma mansoni egg-induced granulomatous inflammation. J Exp Med 1993; 177(6): 1551-1559.

45. Lee MT, Kaushansky K, Ralph P, Ladner MB. Differential expression of M-CSF, G-CSF and GM-CSF by human monocytes. J Leuk Biol 1990; 47: 275-282.

46. Herrman F, Oster W, Meuer SC, Lindemann A, Mertelsmann $\mathrm{RH}$. Interleukin-1 stimulates T-lymphocytes to produce granulocyte-macrophage colony-stimulating factor. J Clin Invest 1988; 81: 1415-1418.
47. Broudy VC, Kaushansky K, Segal GM, Harlam JM, Adamson JW. Tumor necrosis factor- $\alpha$ stimulates human endothelial cells to produce granulocyte-macrophage colony-stimulating factor. Proc Natl Acad Sci USA 1987; 83: 7467-7471.

48. Zucali JR, Dinarello CA, Oblon DJ, Gross MA, Anderson L, Weiner RS. Interleukin-1 stimulates fibroblasts to produce granulocyte-macrophage colony-stimulating activity and prostaglandin $\mathrm{E}_{2} . \quad J$ Clin Invest 1986; 77 : 1857-1863.

49. Marini M, Soloperto M, Mezetti M, Fasoli A, Mattoli S. Interleukin-1 binds to specific receptors on human bronchial epithelial cells and upregulates granulocyte-macrophage colony-stimulating factor synthesis and release. Am J Respir Cell Mol Biol 1991; 4: 519-524.

50. Cox G, Ohtoshi T, Vancheri C, et al. Promotion of eosinophil survival by human bronchial epithelial cells and its modulation by steroids. Am J Respir Cell Mol Biol 1991; 4: 525-531.

51. Strieter RM, Phan SH, Showell HJ, et al. Monokineinduced neutrophil chemotactic factor gene expression in human fibroblasts. J Biol Chem 1989; 264: 10621-10626.

52. Strieter RM, Standiford TJ, Rolfe MW, Kunkel SL. Interleukin-8. In: Kelley J, ed. Cytokines of the Lung. New York, Marcel Dekker, 1993; pp. 281-305.

53. Vancheri C, Ohtoshi T, Cox G, et al. Neutrophilic differentiation by human upper airway fibroblast-derived granulocyte/macrophage colony-stimulating factor (GMCSF). Am Respir Cell Mol Biol 1991; 4: 11-17.

54. Johnsson A, Heldin CH, Westermark B, Wateson A. Platelet-derived growth factor: identification of constituent polypeptide chains. Biochem Biophys Res Commun 1982; 104: 66.

55. Raines EW, Bowen-Pope DF, Ross R. Platelet-derived growth factor. In: Sporn MB, Roberts AB, eds. Handbook of Experimental Pharmacology. Vol. 95. Peptide growth factors and their receptors. Heidelberg, Springer-Verlag, 1990; pp. 173-262.

56. Raines EW, Dower SK, Ross R. Interleukin-1 mitogenic activity for fibroblasts and smooth muscle cells is due to PDGF-BB. Science 1989; 243: 393-396.

57. Paulsson Y, Austgulen R, Hofsli E, Heldin CH, Westermark B, Nissen-Meyer J. Tumor necrosis factor-induced expression of platelet-derived growth factor A-chain messenger RNA in fibroblasts. Exp Cell Res 1989; 180: 490-496.

58. Battegay EJ, Raines EW, Seifert RA, Bowen-Pope DF, Ross R. TGF- $\beta$ induces bimodal proliferation of connective tissue cells via complex control of autocrine PDGF loop. Cell 1990; 63: 515-524.

59. Martinet Y, Rom WN, Grotendorst GR, Martin GR, Crystal RG. Exaggerated spontaneous release of plateletderived growth factor by alveolar macrophages from patients with idiopathic pulmonary fibrosis. $N$ Engl J Med 1987; 317: 202-209.

60. Antoniades HN, Bravo MA, Avila RE, et al. Plateletderived growth factor in idiopathic pulmonary fibrosis. $J$ Clin Invest 1990; 6: 1055-1064.

61. Fabisiak JP, Evans JN, Kelley J. Increased expression of PDGF-B (c-sis) mRNA in rat lung precedes DNA synthesis and tissue repair during chronic hyperoxia. $A m$ J Respir Cell Mol Biol 1989; 1: 181-189.

62. Snyder LS, Hertz MI, Peterson MS, et al. Acute lung injury: pathogenesis of intra-alveolar fibrosis. J Clin Invest 1991; 88: 663-673.

63. Roberts $\mathrm{AB}$, Sporn MB. The transforming growth factorsB. In: Sporn $\mathrm{MB}$, Roberts $\mathrm{AB}$, eds. Handbook of 
Experimental Pharmacology. Vol. 95. New York, Springer-Verlag, 1990; pp. 419-472.

64. Kelley J. Transforming growth factor- $\beta$. In: Kelley J, ed. Cytokines of the Lung. New York, Marcel Dekker, 1992; pp. 101-132.

65. Grotendorst GR, Smale G, Pencev D. Production of transforming growth factor- $\beta$ by human peripheral blood monocytes and neutrophils. J Cell Physiol 1989; 140: 396-402.

66. Leof EB, Proper JA, Goustin AS, Shipley GD, DiCorleto $\mathrm{PE}$, Moses HL. Induction of $c$-cis mRNA and activity similar to platelet-derived growth factor by transforming growth factor- $\beta$ : a proposed model for indirect mitogenesis involving autocrine activity. Proc Natl Acad Sci USA 1986; 83: 2453-2457.

67. Kelley J, Shull S, Walsh JJ, Cutroneo KR, Absher M. Auto-induction of transforming growth factor- $\beta$ in human lung fibroblasts. Am J Respir Cell Mol Biol 1993; 8 . 417-424.

68. Fine A, Goldstein RH. The effect of transforming growth factor- $\beta$ on cell proliferation and collagen formation by lung fibroblasts. J Biol Chem 1987; 262: 3897-3902.

69. Dean DC, Newby RF, Bourgeois S. Regulation of fibronectin biosynthesis by dexamethasone, transforming growth factor- $\beta$, and c-AMP in human cell lines. $J$ Cell Biol 1988; 106: 2159-2170.

70. Bassols A, Massague J. Transforming growth factorbeta regulates the expression and structure of extracellular matrix chondroitin/dermatan sulfate proteoglycans. J Biol Chem 1988; 263: 3039-3045.

71. Westergren-Thorsson G, Särnstrand B, Fransson LA, Malmstrom A. TGF- $\beta$ enhances the production of hyaluronan in human lung but not in skin fibroblasts. Exp Cell Res 1990; 186: 192-195.

72. Limper AH, Broekelmann TJ, Colby TV, Malizia G, McDonald JA. Analysis of local mRNA expression for extracellular matrix proteins and growth factors using in situ hybridization in fibroproliferative lung disorders. Chest 1991; 99: 55S-56S.

73. Khalil N, O'Connor RN, Unruh HW, et al. Increased production and immunohistochemical localisation of transforming growth factor- $\beta$ in idiopathic pulmonary fibrosis. Am J Respir Cell Mol Biol 1991; 5: 155162.

74. Broekelmann TJ, Limper AH, Colby TV, McDonald JA. Transforming growth factor- $\beta$ is present at sites of extracellular matrix gene expression in human pulmonary fibrosis. Proc Natl Acad Sci USA 1991; 88: 66426646.

75. Tsunawaki S, Sporn M, Ding A, Nathan C. Deactivation of macrophages by transforming growth factor- $\beta$. Nature 1988; 334: 260-262.

76. Espevik T, Figari IS, Shalaby MR, et al. Inhibition of cytokine production by cyclosporin A and transforming growth factor- $\beta$. J Exp Med 1987; 166: 571-576.

77. Ranges GE, Figari IS, Espevik T, Palladino MA. Inhibition of cytokine T-cell development by transforming growth factor- $\beta$ and reversal by tumor necrosis factor-

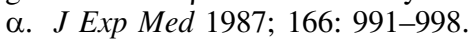

78. Shull MM, Ormsby I, Kier AB, et al. Targeted disruption of the mouse transforming growth factor- $\beta_{1}$ gene results in multifocal inflammatory disease. Nature 1992; 359: 693-699.

79. Oppenheim JJ, Neta R. Pathophysiological role of cytokines in development, immunity, and inflammation. FASEB J 1994; 8: 158-162.

80. Stiles AD, D'Ercole AJ. The insulin-like growth factors and the lung. Am J Respir Cell Mol Biol 1990; 3: 93-100.

81. Stiles AD, Moats-Staats BM. Production and action of insulin-like growth factor 1 /somatomedin $\mathrm{C}$ in primary cultures of fetal lung fibroblasts. Am J Respir Cell Mol Biol 1989; 1: 21-26.

82. Stiles AD, Moats-Staats BM, Retsch-Bogart. Insulinlike growth factors. In: Kelley J, ed. Cytokines of the Lung. New York, Marcel Dekker, 1992; pp. 77-99.

83. Elias JA, Zitnik RJ, Ray P. Fibroblast immune effector function. In: Phipps RP, ed. Pulmonary Fibroblast Heterogeneity. Boca Raton, Florida, CRC Press, 1992; pp. 295-322.

84. van de Rest M, Gorrone R. Collagen family of proteins. FASEB J 1991; 5: 2814-2823.

85. Adams CL. Collagen gene expression. Am J Respir Cell Mol Biol 1989; 1: 161.

86. Sayer JM, Hutcheson ET, Kang AH. Collagen polymorphism in idiopathic pulmonary fibrosis. J Clin Invest 1976; 57: 1498-1507.

87. Starcher BC. Determination of the elastin content of tissues by measuring desmosine and isodesmosine. Ann Biochem 1977; 79: 11-15.

88. Ayad S, Boot-Handford RP, Humphries MJ, Kadler KE, Shuttleworth CA. In: The Extracellular Matrix Facts Book. San Diego, Academic Press, 1994.

89. Ruoslahti E. Structure and biology of proteoglycans. Ann Rev Cell Biol 1988; 4: 229-255.

90. Hardingham TE, Fosang AJ. Proteoglycans: many forms and many functions. FASEB $J$ 1992; 6: 861-870.

91. Kjellen L, Lindahl U. Proteoglycans: structures and interactions. Аnnu Rev Biochem 1991; 60: 443-475.

92. Stamenkovic I, Aruffo A, Amiot M, Seed B. The hemopoietic and epithelial forms of CD44 are distinct polypeptides with different adhesion potentials for hyaluronate-bearing cells. EMBO J 1991; 10: 343-348.

93. Brown TA, Bouchard T, St John T, Wayner E, Carter WG. Human keratynocytes express a new CD44 core protein $(\mathrm{CD} 44 \mathrm{E})$ as a heparan-sulfate intrinsic membrane proteoglycan with additional exons. J Cell Biol 1991; 113: 207-221.

94. Aruffo A, Stamenkovic I, Melnick M, Underhill CB, Seed B. CD44 is the principal cell surface receptor for hyaluronate. Cell 1990; 61: 1303-1313.

95. David G. Integral membrane heparan sulfate proteoglycans. FASEB J 1993; 7: 1023-1030.

96. Murakami S, Miyake K, Abe R, Kincade PW, Hodes RJ. Characterization of autoantibody-secreting B-cells in mice undergoing stimulatory (chronic) graft-versus-host reactions: identification of a CD44 population that binds specifically to hyaluronate. J Immunol 1991; 146: 1422-1427.

97. Lesley J, Howes N, Perschl A, Hyman R. Hyaluronan binding function of CD44 is transiently activated on Tcells during in vivo immune response. J Exp Med 1994; 180: 383-387.

98. Albelda SM, Buck CA. Integrins and other cell adhesion molecules. FASEB J 1990; 4: 2868-2880.

99. Ruoslahti E. Integrins. J Clin Invest 1991; 87: 1-5.

100. Ruoslahti E, Pierschbacher MD. New perspectives in cell adhesion: RGD and integrins. Science (Wash., DC) 1987; 238: 491-497.

101. Bissell MJ, Barcellos-Hoff MH. The influence of extracellular matrix on gene expression: is structure the message? J Cell Sci 1987; 8: 327-343.

102. Bissell MJ, Hall HG, Parry G. How does the extracellular matrix direct gene expression. J Theor Biol 1982; 99: 31-68.

103. McDonald JA. Extracellular matrix effects on cell shape 
and gene expression. Current Opin Cell Biol 1989; 1: 995-1101.

104. Newman SL, Tucci MA. Regulation of human monocyte/macrophage function by extracellular matrix. J Clin Invest 1990; 86: 703-714.

105. Eierman DF, Johnson CE, Haskill JS. Human monocyte inflammatory mediator gene expression is selectively regulated by adherence substrates. J Immunol 1989; 142: 1970-1976.

106. Zhou X, Jordana M, Gauldie J. IL-1 $\beta$ and IL-6 gene expression in alveolar macrophages: modulation by extracellular matrices. Am J Physiol (Lung Cell Mol Physiol) 1992; 262: L600-L605.

107. Anwar ARF, Moqbel R, Walsh GM, Kay AB, Wardlaw AJ. Adhesion to fibronectin prolongs eosinophil survival. J Exp Med 1993; 177: 839-843.

108. Burgess WH, Maciag T. The heparin binding (fibroblast) growth factor family of proteins. Аnnu Rev Biochem 1989; 58: 575-606.

109. Roberts R, Gallagher J, Spooncer E, Allen TD, Bloomfield F, Dexter TM. Heparan sulphate bound growth factors: a mechanism for stromal cell mediated haemopoiesis. Nature 1988; 332: 376-378.

110. Thompson RW, Whalen GF, Saunders KB, Hores T, D'Amore PA. Heparin-mediated release of fibroblast growth factor-like activity into the circulation of rabbits. Growth Factors 1990; 3: 221-229.
111. Saksela O, Rifkin DB. Release of basic fibroblast growth factor-heparan sulfate complexes from endothelial cells by plasminogen activator mediated proteolytic activity. J Cell Biol 1990; 110: 767-775.

112. Damon DH, Lobb RR, D'Amore PA, Wagner JA. Heparin potentiates the action of acidic fibroblast growth factor by prolonging its biological half-life. J Cell Physiol 1989; 138: 221-226.

113. Cheifetz S, Andres JL, Massague J. The transforming growth factor- $\beta$ receptor type III is a membrane proteoglycan. J Biol Chem 1988; 263: 16984-16991.

114. Yamaguchi Y, Mann DM, Ruoslahti E. Negative regulation of transforming growth factor- $\beta$ by the proteoglycan decorin. Nature 1990; 346: 281-284.

115. Westergren-Thorsson G, Hernnas J, Sarnstrandt B, Oldberg A, Heinegard D, Malmstrom A. Altered expression of small proteoglycans, collagen, and transforming growth factor- $\beta$ in developing bleomycin-induced pulmonary fibrosis in rats. J Clin Invest 1993; 92: 632637.

116. Border WA, Noble NA, Yamamoto T, et al. Natural inhibitor of transforming growth factor- $\beta$ protects against scarring in experimental kidney disease. Nature 1992; 360: 361-364.

117. Murphy-Ullrich J, Schultz-Cherry S, Hook M. Transforming growth factor- $\beta$ complexes with thrombospondin. Mol Biol Cell 1992; 3: 181-188. 